\title{
RESEARCH OF WEAR RESISTANCE OF WORKING SURFACES OF SHREDDER ROLLS
}

\author{
Alexander Pastukhov, Nataliia Vodolazskaya, Alexan Minasyan, Aleksandr Kolesnikov \\ Belgorod State Agricultural University named after V. Gorin, Russia \\ pastukhov_ag@mail.ru,vnv26@bk.ru, alikmun@yandex.ru, a.c.kolesnikov@mail.ru
}

\begin{abstract}
Operational research observations of roll shredders for agricultural processing materials of varying hardness show that failure of their functioning is mainly due to wear of working surfaces of rolls. In this connection, studies of wear resistance and evaluation of the limit state of the working surfaces of the rollers allow to ensure a real level of their durability. The purpose of the work is to develop a method of calculating specific wear of working elements of roller shredders depending on physical and mechanical properties of the roller material, mill material and the structural and technological parameters of the unit. Research task of the wear test was to determine the integral wear characteristics depending on the combined effect of factors on the wear process. The method of the research includes study of particle kinematics of mill material in the gap between rolls of shredder, estimation of linear wear on working surfaces of rollers caused by abrasive particles and the number of particles acting on unit site of the surface of shredder rolls. The specific value determined by the ratio of wear to productivity of the shredder is used as the criterion of limit state of rolls by durability. The main factors of influence on specific wear are abrasive action of the mill material, mechanical properties of the roll material and kinematic characteristics and geometric parameters of the rolls. Relative difference in comparison of the calculated and experimental data of specific wear does not exceed $10 \%$, which indicates high accuracy of reflection by equation of real process. Consequently, the results of the research allow to control the wear process and to justify structural, technological and operational solutions to increase operational reliability of working elements of the roller shredder.
\end{abstract}

Keywords: rolls, shredder, wear resistance, material, working surfaces, specific wear.

\section{Introduction}

The problem of reliability of process units and wear resistance of their working elements is the main one in mechanical engineering [1]. Operational observations of roll shredders for agricultural process materials of different hardness show that their failure is mainly due to wear of the working surfaces of the rolls in contact with the material being ground, in which crushing and abrasion occur [2].

Working surfaces of rolls undergo cyclic elastic and plastic deformation resulting in fatigue failure. At the same time micro- and macro-crosses are born and propagated on roller surface. During operation, scratching and micro-cutting takes place, solid grains of the ground material are introduced into the surface of the rollers, which leads to disruption of its continuity and eventually leads to wear and tear $[3 ; 4]$.

The problem of increasing wear resistance of working surfaces of shredders is solved by studying their wear patterns under different friction conditions and surface layer quality. However, the wear process is complex, and the variety of factors influencing wear is large that despite the abundance of research in tribology there are no reliable methods of protecting equipment from intense wear and tear $[5 ; 6]$.

In this connection, for studies of wear resistance and development of a procedure for calculating specific wear depending on the physical and mechanical properties of the material of the rollers, the material should be ground and the structural and technological parameters of the unit, as well as the limit state of the working surfaces of the rollers evaluated that allows to ensure a real level of their durability.

\section{Materials and methods}

The research task of the wear test was to determine the integral wear characteristic depending on the combined effect of factors on the wear process. To this end, the kinematics of the movement of the particulate material in the gap between the rolls (Fig. 1). A probabilistic representation of the movement speed of the abrasive particle as a linear combination of surface speeds was introduced by formula (1).

$$
V=\alpha \cdot V_{1}+\beta \cdot V_{2} ; \alpha+\beta=1,
$$


where $V_{1}$ and $V_{2}-$ surface speeds, $\mathrm{m} \cdot \mathrm{s}^{-1}$;

$\alpha$ and $\beta$ - probabilities of particle fixing, respectively, on the surfaces of rollers 1 and 2 .

The wear of the roll surface depends on the movement characteristics of the particles. They are the movement speed of the particle relative to the roll surfaces; the length of traces left by the particle on the roll surfaces; contact time and microvolume of materials deformed or separated by abrasive particles. For theoretical calculation of the amount of abrasive wear, a spherical model of the ground particle characterized by the radius $r$ was used. The mechanical properties of the particles are characterized by the value of the engineering stress $\sigma_{\mathrm{y}}$, since the wear of the rolls is related to intensive crushing of the abrasive particles.

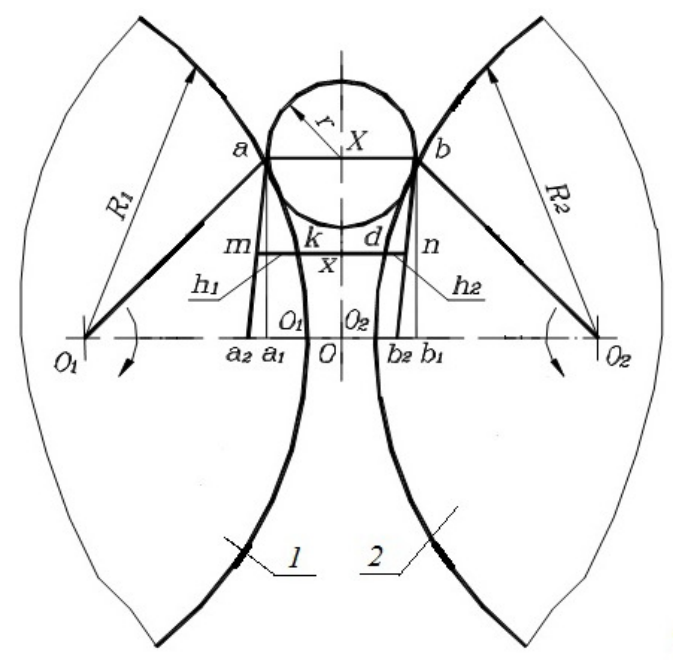

Fig. 1. Diagram of abrasive particle movement in roll gap:

1,2 -rollers; $\mathrm{r}$ - average radius of the abrasive particle, $\mathrm{m} ; \mathrm{h}_{1}, \mathrm{~h}_{2}$ - crushing depth of particles in surfaces of rolls 1 and $2, \mathrm{~m} ; R_{1}, R_{2}$ - radius of roll curvature, $\mathrm{m}$

Moving in the gap between the rolls with increasing diffusion into the roll material, the abrasive particle deforms some volume of the working surface materials. The first path $x$ is determined by formula (2) [7].

$$
x=\sqrt{\frac{R}{r}} \cdot \frac{h_{1}}{H B_{2}}\left(H B_{1}+H B_{2}\right)=\sqrt{\frac{R}{r}} \cdot \frac{h_{2}}{H B_{1}}\left(H B_{1}+H B_{2}\right),
$$

where $\mathrm{HB}_{1}$ and $\mathrm{HB}_{2}$ - hardness of the material of rolls, $\mathrm{MPa}$;

$r$ - radius of the ground particle, $\mathrm{m}$;

$h$-crushing depth, m;

$\mathrm{R}$ - relative radius of curvature of rolls, $\mathrm{m}$, defined by the formula

$$
R=\frac{R_{1} \cdot R_{2}}{R_{1}+R_{2}}
$$

After dividing the detected path (2) by the speed (1), we determine the time $T$ of movement of the abrasive particle in the gap between the rollers until the crushing depth $h$ is reached in formula (3).

$$
T=\sqrt{\frac{R}{r}} \cdot \frac{h_{1}\left(H B_{1}+H B_{2}\right)}{H B_{2}\left(\alpha V_{1}+\beta V_{2}\right)}=\sqrt{\frac{R}{r}} \cdot \frac{h_{2}\left(H B_{1}+H B_{2}\right)}{H B_{1}\left(\alpha V_{1}+\beta V_{2}\right)} .
$$

We find the movement speeds of the particle relative to the surfaces for determination the lengths of traces $\mathrm{L}_{1}$ and $\mathrm{L}_{2}$ left by the abrasive particle on each surface of the rollers. Let us stop at surface 1 (Fig. 1). Speed of relative movement of the abrasive particle along it $\left(V_{\mathrm{O} 1}\right)$ is found as speed difference:

$$
V_{o 1}=\alpha V_{1}+\beta V_{2}-V_{1} ; V_{o 1}=\beta\left(V_{2}-V_{1}\right) .
$$

Therefore, 


$$
V_{o 2}=\alpha\left(V_{1}-V_{2}\right) .
$$

The speed of relative motion is multiplied by the contact time (3) for determination $L$ :

$$
L=V_{o 1} \cdot T=\sqrt{\frac{R}{r}} \cdot \frac{\beta\left(V_{2}-V_{1}\right) \cdot h\left(H B_{1}+H B_{2}\right)}{H B_{2} \cdot\left(\alpha V_{1}+\beta V_{2}\right)},
$$

since hardness is a determinant of the crushing depth of the indenter into the surface, then the mean of $\alpha$ and $\beta$ approximately can be taken inversely proportional to the hardness of the roll surfaces (Brinel):

$$
\alpha=\frac{H B_{2}}{H B_{1}+H B_{2}} ; \beta=\frac{H B_{1}}{H B_{2}+H B_{1}},
$$

let us receive

$$
L_{1}=\sqrt{\frac{R}{r}} \cdot \frac{\left(V_{1}-V_{2}\right) \cdot H B_{1}}{H B_{2} \cdot\left(\alpha V_{1}+\beta V_{2}\right)} .
$$

A similar formula is obtained for $L_{2}$ from expression (7) by changing indexes.

Using expressions (7), the deformed volume for the roll surface 2 (Fig. 1) is defined in formula $(8)$.

$$
V_{2}=\frac{\sqrt{2}}{3} \cdot h_{2}^{2.5} \cdot \sqrt{R} \frac{H B_{2}\left(V_{1}-V_{2}\right)}{H B_{1}\left(\alpha V_{1}+\beta V_{2}\right)} .
$$

We get the same for $V_{1}$.

Expressing deformed volumes through the I.B. Kragelsky criterion $K=h / r$ [8], we obtain

$$
V=\frac{\sqrt{2}}{3} \cdot K^{2.5} \cdot r^{2.5} \cdot \sqrt{R} \frac{\left|V_{1}-V_{2}\right| \cdot H B_{2}}{\left(\alpha V_{1}+\beta V_{2}\right) \cdot H B_{1}} .
$$

Depending on the value $K$, the microvolume of the contacting surfaces will undergo elastic, plastic deformation or micro-cutting. Given this, the deformed volume excited by a single abrasive particle can be divided into three parts (Fig. 2): elastic deformation volume $\left(V_{y}\right)$, plastic deformation volume $\left(V_{n}\right)$ and micro-cutting volume $\left(V_{M}\right)$

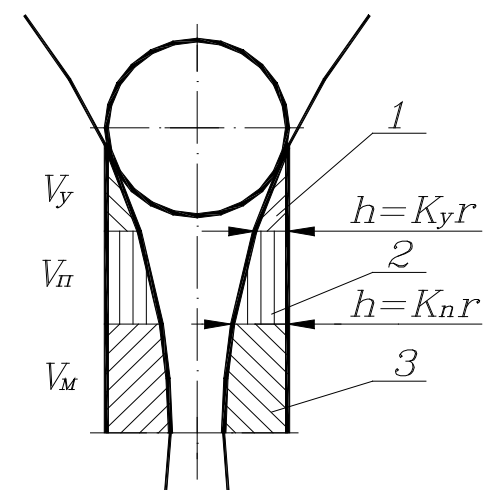

Fig. 2. Areas of the deformed volumes: 1 - elastic, 2 - plastic, 3 - microcutting

Formulas for calculating these parts are derived from expressions (9) and geometric builds in the form of formulas (10)-(12).

$$
\begin{gathered}
V_{y}=\frac{\sqrt{2}}{3} \cdot K^{2.5} \cdot r^{2.5} \cdot \sqrt{R} \frac{\left|V_{1}-V_{2}\right|}{\alpha V_{1}+\beta V_{2}} ; \\
V_{n}=\frac{\sqrt{2}}{3} \cdot\left(K_{n u}^{2.5}-K_{y n}^{2.5}\right) \cdot r^{2.5} \cdot \sqrt{R} \frac{\left|V_{1}-V_{2}\right|}{\alpha V_{1}+\beta V_{2}} ;
\end{gathered}
$$




$$
V_{M}=\frac{\sqrt{2}}{3} \cdot\left(K^{2.5}-K_{n u}^{2.5}\right) \cdot r^{2.5} \cdot \sqrt{R} \frac{\left|V_{1}-V_{2}\right|}{\alpha V_{1}+\beta V_{2}} .
$$

where $K, K_{y n}, K_{n n}-$ I.B. Kragelsky's criterion in areas elastic, elasto-plastic and plastic microcutting, respectively.

Now we will determine which of these deformations will be realized and which of the parts of the deformed microvolume (Fig. 2) should be taken into account when assessing wear.

Analysis has shown that wear of roll surfaces occurs more due to repeated elastic and plastic deformations. In the case of cyclic plastic deformation the volumetric wear can be estimated by the amount of deformed volume divided by the numbers of resulting cycles $n_{f}$. For determination of the linear wear of $U_{\mathrm{h}}$, the result should be divided by the area of the wear surface $S_{a}$ in formula (13).

$$
\Delta U_{h}=\frac{V}{n_{f} \cdot S_{a}} .
$$

Maximum depth of the deformed volume is in keeping with the moment of its crushing. This determines the value of the deformed volume. Then, the linear wear produced by a single particle before it is broken, according to equation (9), taking into account $n_{f}=\varepsilon_{0}{ }^{t}$ for surface 1 , is defined in formula (14).

$$
\Delta h_{h 1}=\frac{\sigma^{2.5} \cdot r^{2.5} \cdot \sqrt{R} \cdot\left|V_{1}-V_{2}\right|}{12 H B_{1}^{1.5} \cdot H B_{2} \cdot \varepsilon_{0}^{t} \cdot S_{a} \cdot\left(\alpha V_{1}+\beta V_{2}\right)},
$$

where $\varepsilon_{0}$ - elongation at failure, $\%$;

$t$ - fatigue ratio for plastic deformations of the roll material.

The abrasive particle is crushed into a large number of fragments into the gap between the rolls reaching a certain crushing depth. Then repeated crushing occurs until the particles become smaller than the roll gap and pass the contact zone. The additional wear caused by the formed particles is taken into account by the crushing factor $K_{\partial p}[9 ; 10]$. Knowing the amount of wear and the number of particles, we sum the damage. Thus, the wear of the entire working surface of the shredder rolls was evaluated.

Linear wear of the roll surface with area $S_{\mathrm{a}}$ for time $\mathrm{t}$ is equal to [10]

$$
U_{h}=\sum_{S_{a}} \sum_{t} n_{\Delta S} \cdot \Delta h_{h} \cdot \Delta S_{a} \cdot \Delta t
$$

where $n_{\Delta S}$ - number of particles on the edge of the unit cube, pcs;

$\Delta \Lambda_{h}$ - total wear caused by a particle of the radius $r$ and all its splinters formed as a result of crushing, $\mathrm{m} \cdot \mathrm{h}^{-1}$.

Knowing the value of linear wear we can determine its volumetric wear

$$
U_{V}=U_{v} \cdot S_{6} \text {, }
$$

where $U_{v}$ - linear wear rate, $\mathrm{m} \cdot \mathrm{h}^{-1}$;

$S-$ roll surface area $\left.S_{\theta}=\pi \cdot D_{\theta} \cdot B\right), \mathrm{m}^{2}$. $h_{\mathrm{G}}, \mathrm{m}$,

By multiplying the expression (16) by the density of the roll material, we obtain the weight wear

$$
h_{G}=h_{V} \cdot \rho=h_{v} \cdot \pi \cdot D_{s} \cdot B \cdot \rho .
$$

However, it is advisable to use the specific wear criterion, which allows to estimate the quantitative value of wear from the productivity of the unit in formula (18).

$$
U_{y}=\frac{h_{G}}{Q}=\frac{4,55 \cdot \varepsilon^{2 / 3} \cdot \sigma_{y}^{2,5} \cdot r^{0,5} \cdot \sqrt{R} \cdot\left|V_{1}-V_{2}\right| \cdot \rho \cdot \cos \gamma}{H B^{2,5} \cdot \varepsilon_{0}^{t} \cdot\left(\alpha V_{1}+\beta V_{2}\right) \cdot\left[D_{c p} \cdot\left(1-\cos \alpha_{0}\right)+\delta\right] \cdot \rho_{0}},
$$


where $\varepsilon$-concentration of abrasive particles in the unit volume between the rolls, $\%$;

$r$ - average radius of the abrasive particle, $\mathrm{m}$;

$\rho$ - density of the roll material, $\mathrm{g} \cdot \mathrm{m}^{-3}$;

$\gamma$ - roll cone angle, deg;

$H B$ - hardness of the roll material, $\mathrm{MPa}$;

$\varepsilon_{0}$ - percent elongation of the roll material at break, \%;

$t$ - fatigue ratio for plastic deformations of the roll material;

$D_{\mathrm{cp}}$ - average diameter of rollers, $\mathrm{m}$;

$\alpha_{0}-$ angle of sealing and deformation;

$\delta$ - value of gap between rolls, $\mathrm{m}$;

$\rho_{0}$ - bulk mass of ground material till its deformation, $\mathrm{t} \cdot \mathrm{m}^{-3}$;

$R$ - relative radius of curvature of rolls, $\mathrm{m}$.

To analyze the specific wear of the rolls, we show three groups of factors characterizing: 1) abrasive action $-A$; 2) mechanical properties of roll materials $-M$; 3) kinematic and geometric parameters of rolls $-K$, according to formulas (19)-(21).

$$
\begin{gathered}
A=\frac{\varepsilon^{2 / 3} \cdot \sigma_{y}^{2,5} \cdot r^{0.5}}{\rho_{0}} ; \\
K=\frac{\sqrt{R} \cdot\left|V_{1}-V_{2}\right| \cdot \cos \gamma}{\left(\alpha V_{1}+\beta V_{2}\right) \cdot\left[D_{c p}\left(1-\cos \alpha_{0}\right)+\delta\right]} \\
M=\frac{\varepsilon_{0}^{t} \cdot H B^{2,5}}{\rho}
\end{gathered}
$$

\section{Results and discussion}

As an example, we will calculate the value of specific wear from the obtained equation (18) for bone grinding, with different factors of groups $\mathrm{M}$ and $\mathrm{K}$, and we will construct a graphical dependence of $h_{\mathrm{y}}=f\left(H B ; K_{\phi} ; \delta\right)$ at the following basic data: $\sigma_{\mathrm{y}}=76 \mathrm{MPa} ; \varepsilon=73 \% ; R=0.1 \mathrm{~m} ; r=4 \cdot 10^{-3} \mathrm{~m}$; $\rho=7.8 \cdot 10^{6} \mathrm{~g} \cdot \mathrm{m}^{-3} ; \gamma=0^{\circ} ; \alpha=\beta=0.5 ; D_{\mathrm{cp}}=0.4 \mathrm{~m} ; \alpha_{\mathrm{o}}=5^{\circ} ; \rho_{\mathrm{o}}=1.49 \mathrm{t} \cdot \mathrm{m}^{-3}$.

The calculated data and average values for the experiment are summarized in Table 1 and presented in Fig. 3.

\begin{tabular}{|c|c|c|c|c|c|c|}
\hline \multicolumn{5}{|c|}{ Modify parameters } & \multicolumn{2}{|c|}{ Specific wear $\boldsymbol{U}_{\mathrm{v}}, \mathbf{g} \cdot \mathbf{t}^{-1}$} \\
\hline$V_{1}, \mathrm{~m} \cdot \mathrm{s}^{-1}$ & $V_{2}, \mathrm{~m} \cdot \mathrm{s}^{-1}$ & $\varepsilon, \%$ & $H B, \mathrm{MPa}$ & $\delta, \mathrm{m}$ & Calculated & Experimental \\
\hline \multirow{5}{*}{0.127} & \multirow{5}{*}{0.105} & 1243.21 & 1800 & \multirow{5}{*}{0.0015} & 14.922 & 12.837 \\
\hline & & \multirow{2}{*}{733.36} & 2400 & & 12.426 & 11.09 \\
\hline & & & 3800 & & 6.026 & 6.539 \\
\hline & & \multirow{2}{*}{324.00} & 5200 & & 4.081 & 4.495 \\
\hline & & & 5800 & & 3.266 & 3.365 \\
\hline \multirow{4}{*}{0.127} & \multirow{4}{*}{0.105} & \multirow{4}{*}{733.36} & \multirow{4}{*}{2400} & 0.0015 & 12.426 & 11.090 \\
\hline & & & & 0.0030 & 8.487 & 8.681 \\
\hline & & & & 0.0045 & 6.373 & 6.991 \\
\hline & & & & 0.0051 & 5.796 & 6.790 \\
\hline \multirow{4}{*}{0.127} & 0.105 & \multirow{4}{*}{733.36} & \multirow{4}{*}{2400} & \multirow{4}{*}{0.0030} & 8.486 & 8.681 \\
\hline & 0.075 & & & & 10.492 & 11.399 \\
\hline & 0.058 & & & & 12.837 & 13.580 \\
\hline & 0.053 & & & & 14.412 & 14.490 \\
\hline
\end{tabular}

Calculated and experimental specific roll wear values

Table 1

Table 1 and Fig. 3 show that the average discrepancy between the theoretically and experimentally obtained data does not exceed $10 \%$. This indicates that the resulting equation for determining the specific wear of the working surfaces of the rollers reflects the actual process with sufficient accuracy. 


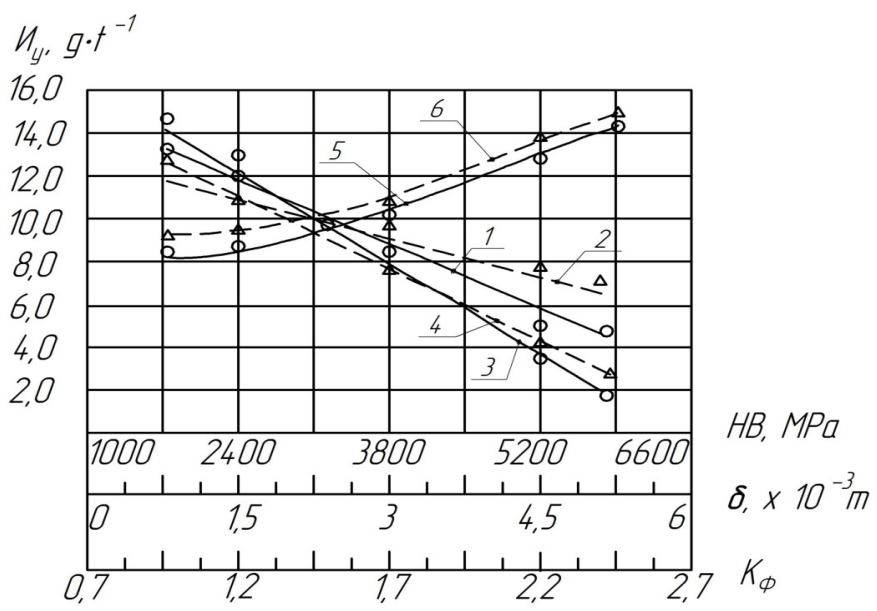

Fig. 3. Graphical comparison of wear on the roll surface: $\Delta$ - calculated; o - experimental; $1,2-h_{\mathrm{y}}=f(\delta) ; K_{\phi}=1.2 ; H B=2400 \mathrm{MPa} ; 3,4-h_{\mathrm{y}}=f(H B) ; K_{\phi}=1.2 ; \delta=1.5 \cdot 10^{-3} \mathrm{~m}$;

$$
5,6-h_{\mathrm{y}}=f\left(K_{\phi}\right) ; H B=2400 \mathrm{MPa} ; \delta=3 \cdot 10^{-3} \mathrm{~m}
$$

Similar studies were carried out on the examples of various foreign agricultural grinding machines, the results of the analyzed works being comparable [11-13]. On the other hand, the presented results can be used in experimental development of various methods to ensure durability of working surfaces of rolls in operation $[14 ; 15]$.

\section{Conclusions}

Based on the synthesis of the above material, the following conclusions can be drawn.

1. Method of estimation and prediction of specific wear of working surfaces of shredder rolls depending on physical and mechanical properties of the roll material, ground material and structural and technological parameters of the unit;

2. Comparison of estimated parameters of the methodology operability shows that the relative error of theoretical and experimental data is not more than $10 \%$, therefore, the obtained mathematical models of specific wear of the working surfaces of the rollers reliably reflect the shreddering process;

3. Consideration and analysis of three groups of factors of physical and mechanical properties of the roll material, ground material and structural and technological parameters of the unit on the basis of the specific wear criterion of rolls, allows to control the wear process, as well as to optimize the main structural and technological solutions in order to increase durability of working surfaces of shredder rolls in operation.

\section{References}

[1] Lamberson L.R., Kapur K.S. Reliability in engineering design. Weliy India Pvt. Limited, 2009. $608 \mathrm{p}$.

[2] Srivastava A.K., Goering C.E., Rohrbach R.P., Buckmaster D.R. Engineering Principles of Agricultural Machines. 2 nd Edition. ASABE, 2006. 553 p.

[3] Минасян А.Г., Пастухов А.Г. Методика оптического исследования напряженногодеформированного состояния валков измельчителей (Method of optical examination of stressed-deformed state of shredder rolls) // Инновации в АПК: проблемы и перспективы. 2019. No 1(21). pp.53-60. (In Russian).

[4] Минасян А.Г., Пастухов А.Г., Шарая О.А. Оценка напряженно-деформированного состояния сегмента пресс-валкового измельчителя (Evaluation of stress-strain condition of the press-roll shredder segment) // Технология машиностроения. 2016. № 3. pp.43-46. (In Russian).

[5] Schneider L. T. Energy saving clinker grinding system. Part I. "Word Cement” 1985. № 2 , pp. 20-27.

[6] Schneider L. T. Energy saving clinker grinding system. Part 2. "Word Cement”, 1985, №3, pp. 80-87. 
[7] Крагельский И.В., Добичин М.Н., Комбаков В.С. Основы расчётов на трение и износ (Basics of friction and wear calculations). М.: Машиностроение, 1977. 528 c. (In Russian).

[8] Крагельский И.В. Трение и износ (Friction and wear). М.: Машгиз, 1962. 383 с. (In Russian).

[9] Гаркунов Д.Н. Триботехника (Tribotekhnik). М.: Наука, 1989. 265 с. (In Russian).

[10]Пальцер Г., Майсснер Ф. Основы трения и изнашивания (Friction and Wear Foundations) / Пер. с нем. под ред. М.Н. Добичина. М.: Машиностроение, 1984. 264 с. (In Russian).

[11] Springis G., Rudzitis J., Gerins E., Leitans A. Rough surface peak influence on the wear process of sliding-friction pairs. Engineering for Rural Development. Jelgava, Latvia, 2016. pp. 14301436.

[12] Savinyh P., Aleshkin A., Nechaev V., Ivanovs S. Simulation of particle movement in crushing chamber of rotary grain crusher. Engineering for Rural Development. Jelgava, Latvia, 2017. pp. 309-316. DOI: 10.22616/ERDev2017.16.N061.

[13] Kaminski J., Sypula M., Chlebowski J., Nowakowski T. Research in rake tines wear. Engineering for Rural Development. Jelgava, Latvia, 2017. pp. 64-71. DOI: 10.22616/ERDev2018.17.N077.

[14]Минасян А.Г. Повышение эксплуатационного ресурса рабочих поверхностей валковых измельчителей (Increased operational life of working surfaces of roller shredders) // Инновации в АПК: проблемы и перспективы. 2018. No 3(19). pp. 38-43. (In Russian).

[15]Водолазская Н.В., Минасян А.Г., Шарая О.А. К вопросу повышения эксплуатационной надежности некоторых видов промышленного оборудования (To the issue of improving the operational reliability of some types of industrial equipment) // Vesnik of Donbass State Mechanical Engineering Academy, 2017, No 1(37), pp. 48-53. (In Russian). 